\title{
Comparative Study on Income Generation through Agriculture Crop and JanVan Yojana Plantation at Farmers Level in Ranchi District of Jharkhand
}

\author{
Md. Shahzad Ahmad ${ }^{1,2^{*}}$, Naheed Irfan ${ }^{3}$, Jyoti Kumar ${ }^{4}$ \\ ${ }^{1}$ Research Scholar, Department of Botany, Ranchi University, Morabadi, Ranchi, India \\ ${ }^{2}$ Department of Forest, Environment and Climate Change, Govt. of Jharkhand, Nepal House, Ranchi, India \\ ${ }^{3}$ Assistant Professor \& HOD, Department of Sociology, Sundarwati Mahila College, Tilka Manjhi Bhagalpur University, \\ Bhagalpur, Bihar, India \\ ${ }^{4}$ University Professor \& HOD, Department of Botany, Ranchi University, Morabadi, Ranchi, India
}

*Address for Correspondence: Md. Shahzad Ahmad, Research Scholar, Department of Botany, Ranchi University, Morabadi, Ranchi-843008, Jharkhand, India

E-mail: ahmadjkd2010@gmail.com

Received: 30 May 2020/ Revised: 29 Aug 2020/ Accepted: 23 Oct 2020

\begin{abstract}
Background: Jharkhand was carved out from Bihar and created as the $28^{\text {th }}$ state of India. The state has a population of 32.9 million, constitutes $75.95 \%$ rural and $24.05 \%$ urban population whereas state capital Ranchi has population of 29.14 Lakhs, out of which, $56.9 \%$ are rural and $43.1 \%$ are urban. The main livelihood and primary source of income of $80 \%$ of the rural population of the state depend on agriculture.

Materials: In the present study, we have done a comparative analysis of the income generation from JanVan Yojana crops as compared to traditional cash crops.

Results: The study results indicate that JanVan Yojana crops i.e. fruit and timber yielding crops are generated higher income than other agricultural crops like paddy, wheat, gram etc. The collective net income generated from the several crop farming system in a year was Rs. 42,550, which is still less than income generated from JanVan Yojana crops.

Conclusion: The study suggests that horticultural fruit crops and silviculture can generate higher income compared to the other traditional crops at farmer's level. It is therefore suggested to the farmers to adopt and incorporate fruit as well as timber crops with the traditional agricultural crops. Hence, Jan Van Yojana must be proved as boon to the farmers in making their income double and also as a stepping stone for the self-sustaining Jharkhand.
\end{abstract}

Key-words: Horticulture, JanVanYojna, Jharkhand, Livelihood agriculture, Ranchi, Silviculture

\section{INTRODUCTION}

Jharkhand was created as the $28^{\text {th }}$ state of India by carving it out from Bihar on $15^{\text {th }}$ November 2000. The literal meaning of Jharkhand is "Land cover with Forest". The Jharkhand is devised by combining two words 'Jhar' means 'bush' and 'Khand' means 'land'. The state has a total geographical area of $79,716 \mathrm{Km}^{2}$ and the total recorded area of the Ranchi district is $5,097 \mathrm{Km}^{2}$.

\section{How to cite this article}

Ahmad MS, Irfan N, Kumar J. Comparative Study on Income Generation through Agriculture Crop and JanVan Yojana Plantation at Farmers Level in Ranchi District of Jharkhand. SSR Inst. Int. J. Life Sci., 2020; 6(6): 2726-2733.

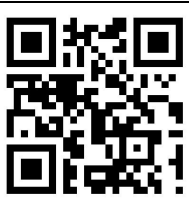

According to the 2011 census, Jharkhand has a population of 32.9 million, which constitutes $75.95 \%$ rural and $24.05 \%$ urban population, whereas as state capital Ranchi district has 29.14 Lakhs population out of which, $43.1 \%$ people lives in urban areas while $56.9 \%$ lives in the rural areas. The state ranks $6^{\text {th }}$ in the scheduled tribe population and ranks $10^{\text {th }}$ in the percentage share of the scheduled tribe population to the total population of the state ${ }^{[1]}$. The total tribal population of the Ranchi district is 10.42 lakhs (35.76\%), out of which 5.20 lakhs are male 5.21 are females. Tribal's socio-cultural life mostly revolves around nature and has a very close relationship with the forest and their life and sustenance are harmonized with available forest resources. Forest and its products play an 
important role in the economic development of Jharkhand ${ }^{[2]}$.

The main livelihood and primary source of income of $80 \%$ of the rural population of the state depend on agriculture. The state agricultural economy is characterized by its dependency on nature, low investment, low productivity, mono-cropping with paddy as the dominant crop, inadequate irrigation facilities and small and marginal holdings. The dependency of agriculture on the unpredictable rainfall can be estimated from the fact that about $92 \%$ of the total cultivated area is un-irrigated. However, negative impacts have been also observed due to agricultural expansion, landscape modification and deforestation on biodiversity, ecosystem services, shifting the species composition and their ecological functions that can significantly alter important ecosystem processes ${ }^{[3-8]}$. On the other hand, a progressively industrialized global economy, rapid population expansion, land degradation, land use pattern and various human activities have led the increased pressure on the natural resources such as the availability of land for sustainable livelihoods, and ecosystems are becoming unsustainable and fragile due overexploitation and extraction of the natural resources since last century ${ }^{[9]}$. To avoid these circumstances, tree (including fruit and timber plants) growing in combination to agriculture, as well as numerous vegetation management regimes, may improve soil fertility, carbon storage, produce fruits, provide fodder, produce fuel-wood and variety of wood products for farmers own use and sale without demanding additional land ${ }^{[8,10]}$. Planting trees and crops in the association can also produce direct financial benefits ${ }^{[11]}$.

Keeping in view all the above points, the State government of Jharkhand has launched an ambitious

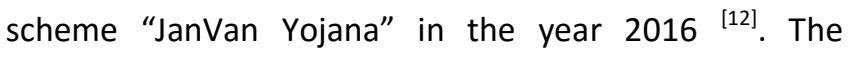
objective of the scheme is to increase the green cover and maintain the Environmental balance, conservation of the underground water by plantation, to reduce the pressure on the notified forest by planting the trees in the private land, to increase the farmer's income as well as to increase forest cover in the state by peoples participation ${ }^{[13]}$. Under the scheme, farmers have to plant trees in their private land and $75 \%$ of the cost incurred over the plantation and maintenance of the planted trees are borne by the forest department (Government of Jharkhand) for first three years ${ }^{[14]}$.
The current study has been carried out to know the actual status of income generated from the plantation of the JanVan yojana crops including both fruit and timber yielding crops as compared to other main crops viz. paddy, wheat, gram, and mustard.

\section{MATERIALS AND METHODS}

Study area- A total of 200 respondents from Angara, Mandar and Burmu Block of Ranchi District were questioned for the structured questionnaire and data collected. Angara, Mandar and Burmu are located $21 \mathrm{~km}$ east, $30 \mathrm{~km}$ west and $37 \mathrm{~km}$ north from District headquarters Ranchi. Angara is surrounded by Ormanjhi Block towards North, Kanke Block towards west, Ranchi Block towards west, Namkum Block towards South. Mandar is surrounded by Ratu Block towards East, Chanho Block towards west, Burmu Block towards North, Bero Block towards South. Burmu is surrounded by Patratu Block towards East, Mandar Block towards South, Chanho Block towards west, Ratu Block towards South. The study has been carried out during the years 2018-19 and 2019-20.

Data collection and analysis- The data collection in this study by questioning respondents was commonly used method and is known to be simple and cheap method. However, the precision of the data depends on the aptitude and skill of the respondents and their truthful replies ${ }^{[15]}$. The previously designed questionnaires containing information regarding the land holding capacity, cropping pattern, cropping intensity, comparative income generated in agricultural and horticultural as well as timber crops of JanVan Yojana and the net return of the generated from different crops. Generally, the questioning was done to one respondent at a time, mostly to the head of the house. The collected data were analyzed to come up with their income structures.

\section{RESULTS}

The agro-climatic conditions of the region are as followsSoil- Soil orders namely Entisols, Inceptisols and Alfisols were observed in Ranchi district. Alfisols were the dominant soils covering $71 \%$ of TGA followed by Inceptisols (17.2\%) and Entisols (9.6\%). 
Rainfall- According to District weather office of Ranchi, the mean of the annual rainfall of Ranchi district was $1295.14 \mathrm{~mm}$ and the corresponding values for seasonal rainfall were $53.77 \mathrm{~mm}$ for winter, $82.43 \mathrm{~mm}$ for premonsoon, $1073 \mathrm{~mm}$ for monsoon and $83.69 \mathrm{~mm}$ for post-monsoon, respectively.

Temperature- Temperature of Ranchi district ranges between Min 5.3 to Max 20.9 in winter and Min 20.6 to Max 41.2 in summer.

Time Scale- The current study was carried out during the year 2018-19 and 2019-20.

Target Group- The present study was conducted among the farmers of the Angara, Mandar and Burmu Block of Ranchi district, Jharkhand, India.

The present study was undertaken to know the income generated from farming of different crops including horticultural and timber crops of JanVan Yojana. The study was carried out in identified villages of Angara, Mandar and Burmu Block of Ranchi district in Jharkhand. The results obtained for different agricultural as well as JanVan yojana crops are given in Tables (1-4).

Crops: Expenditure and Income analysis- For one acre plantation of paddy in rainy and summer seasons Rs. 22,185 and 27,160 was required as the cost of production, respectively. Total cost of production comprises the quantity of seed (35 kg) @ Rs. 1610, Land preparation @ Rs. 2000, Insecticides @ Rs. 1100 (in the rainy season) and Rs. 1600 (in summer season), FYM @
Rs. 1500, Fertilizer @ Rs. 1875 (in rainy season) and Rs. 2350 (in summer season) and total Labour cost (for 73 MDS) @ Rs. 14,600. Total return comes from one acre land is around Rs. 43,115 (in rainy season) and Rs. 37,670 (in summer season) and the net profit in rainy season was Rs. 20,930 and in summer season was Rs. 10,510 (Table 1).

We observed that for cultivation of Wheat in one acre of land, farmers spend approximately Rs. 13,600. The total production cost includes seeds cost (50 kg) @ Rs. 2750, land preparation cost @ Rs. 900, FYM @ Rs. 1000, Insecticides @ Rs. 500, Fertilizer @ Rs. 1,650, Irrigation @ Rs. 2200 and Labour cost @ Rs. 4,600. The gross income and net income generated are Rs. 19,250 and Rs. 5650 , respectively (Table 1 ).

The current study shows that, for Mustard cultivation in one acre land, farmers require spending Rs. 11,125 as the total production cost includes (i) Cost of seeds- Rs. 225 (ii) land preparation cost- Rs. 900 (iii) FYM- Rs. 1000 (iv) Fertilizer- Rs. 900 (v) Irrigation- Rs. 600 (vi) Insecticides- Rs. 500 (vii) Labour- Rs. 7000. The total return from cultivation one acre land of Mustard was Rs. 26,550 and net income was Rs. 15,425 (Table 1).

However, for the cultivation of Grams in one acre land, the total cost of production was Rs. 14,000 and farmer's get net profit of Rs. $12,812.50$ with Gross income was Rs. $29,812.50$. The total cost of production includes seeds cost (30 kg) @ Rs. 4500, cost of land preparation @ Rs. 750, FYM @ Rs. 1000, Fertilizer including Rhizobium @ Rs. 650, cost of irrigation @ Rs.600, insecticides @ Rs. 500 and total labour cost @ Rs.6,000 (Table 1).

Table 1: Analysis of cost incurred and income generated from different agricultural cash crops

\begin{tabular}{|c|c|c|c|c|c|}
\hline \multirow{3}{*}{ For one acre land } & \multicolumn{5}{|c|}{ Cost (Rs.) } \\
\hline & \multicolumn{2}{|c|}{ Paddy } & \multirow{2}{*}{$\begin{array}{l}\text { Wheat } \\
\text { Winter }\end{array}$} & \multirow{2}{*}{$\begin{array}{c}\text { Mustard } \\
\text { Winter }\end{array}$} & \multirow{2}{*}{ Gram } \\
\hline & Rainy & Summer & & & \\
\hline \multirow[t]{3}{*}{ Seed } & (35 kg) @Rs. & (35 kg) @Rs. & (50 kg) @Rs. & (2.5 kg) @Rs. & (30 kg) @Rs. \\
\hline & $46 / \mathrm{Kg}=$ & $46 / \mathrm{Kg}=$ & $50 / \mathrm{Kg}=$ & $90 / \mathrm{Kg}=$ & $150 / \mathrm{Kg}=$ \\
\hline & 1610 & 1610 & 2750 & 225 & 4500 \\
\hline $\begin{array}{l}\text { Preparation of } \\
\text { land }\end{array}$ & 2000 & 2000 & 900 & 900 & 750 \\
\hline \multirow{2}{*}{$\begin{array}{l}\text { Insecticides } \\
\text { Fertilizer }\end{array}$} & 1100 & 1600 & 500 & 500 & 500 \\
\hline & 1875 & 2350 & 1650 & 900 & $\begin{array}{c}650 \text { (including } \\
\text { Rhizobium) }\end{array}$ \\
\hline FYM & 1500 & 1500 & 1000 & 1000 & 1000 \\
\hline Irrigation & - & 3500 & 2200 & 600 & 600 \\
\hline
\end{tabular}




\section{Total Labour Cost}

Total cost

Production

Paddy Straw

Gross Income

Net Income =

Gross Income -

Total Cost

\section{MDS @ \\ Rs. $200 / \mathrm{MD}=$ \\ 14,600 \\ 73 MDS @ \\ Rs. $200 / \mathrm{MD}=$ \\ 14,600}

22,185
21 Quintal @
Rs.1815 /
Quintal =
38,115

18 Quintal @ Rs.

$1815 /$ Quintal $=$

5000

43,115

20,930
27,160

32,670

\section{MDS @}
Rs. $200 / \mathrm{MD}=$ 4600

13,600

10 Quintal @

Rs.1925 /

Quintal =

19,250

5000

37,670

10,510

19,250

5650

\section{MDS @ \\ Rs. $200 / \mathrm{MD}=$ \\ 7000}

11,125

$$
\begin{gathered}
6 \text { Quintal @ } \\
\text { Rs.4425 / } \\
\text { Quintal = } \\
26,550
\end{gathered}
$$

26,550

15,425
30 MDS @

Rs. $200 / \mathrm{MD}=$

6000

14,000

5.5 Quintal @

Rs.4875 / Quintal

$=$

$26,812.50$

$26,812.50$

$12,812.50$

JanVan Yojana crops: expenditure and income analysisAccording to the Yojana, there was a provision of planting 445 numbers of the timber yielding plant species viz. Rosewood, Teak, Ghamar, mahogany, Clonal Eucalyptus and Acacia whereas, 160 numbers of fruit yielding plant species viz. Kalmi Mango, Guava, Amla, Litchi, Jackfruit and Bael in acre of the private land of the selected farmers. The total cost incurred during the first 3 years of the plantation of the timber yielding plants was Rs. 28,602 and for fruit yielding plants was Rs. 32,438 . The total cost incurred during $1^{\text {st }}$ year of plantation includes (i) Labour costs- Rs. 7975.99 (for timber yielding plants) and Rs. 13,893.66 (for fruit yielding plants) (ii) Total cost of plants including transportation- Rs. 8900 (for timber yielding plants @ Rs. 20/plant) and Rs. 9600 (for fruit yielding plants @ Rs. 60/plant) (iii) Fertilizer and Insecticides- Rs.700 (for timber yielding plants) and Rs. 16,00 (for fruit yielding plants) (Table 2). The cost incurred during $2^{\text {nd }}$ year of plantation includes (i) Labour costs- Rs. 1776 (for timber yielding plants) and Rs. 1184 (for fruit yielding plants) (ii) Fertilizer and Insecticides - Rs. 350.45 (for timber yielding plants) and Rs. 800 (for fruit yielding plants) (iii) Irrigation- Rs. 4450 (for timber yielding plants) and Rs. 1600 (for fruit yielding plants) (Table 2). The cost incurred during $3^{\text {rd }}$ year of plantation includes (i) Labour costs- Rs. 1360 (for fruit yielding plants) (ii) Fertilizer and Insecticides- Rs. 800 (for fruit yielding plants) (iii)

\begin{tabular}{|c|c|c|}
\hline \multirow[t]{2}{*}{ For one acre land } & \multicolumn{2}{|c|}{ Cost incurred during first year of Plantation (Rs) } \\
\hline & $\begin{array}{l}\text { Fruit yielding Plants of JanVan } \\
\text { Yojana (160 plants per acre) }\end{array}$ & $\begin{array}{l}\text { Timber yielding Plants of JanVan } \\
\text { Yojana (445 plants per acre) }\end{array}$ \\
\hline Total labour cost incurred on field & 26 days $X$ Rs. $257.29 /$ days $=$ & 10 days $X$ Rs. $257.29 /$ days $=$ \\
\hline preparation for plantation & 6689.54 & 2572.90 \\
\hline \multicolumn{3}{|l|}{ Labour cost@257.29 per day } \\
\hline Total cost of plants including transportation & 160 plants per acre $X$ Rs. & 445 plants per acre X Rs. 20/plant \\
\hline Fruit yielding plant@Rs 60/ plant \& & $60 /$ plant $=$ & $=$ \\
\hline Timber yielding plant @Rs 20/timber plant & 9600 & 8900 \\
\hline labour cost incurred on making prescribed & 24 days $X$ Rs. $257.29 /$ days $=$ & 10 days $X$ Rs. $257.29 /$ days $=$ \\
\hline pit for Plantation & 6174.96 & 2572.90 \\
\hline labour cost incurred on two weeding & 4 days $X$ Rs. $257.29 /$ days $=$ & 11 days $X$ Rs. $257.29 /$ days $=$ \\
\hline
\end{tabular}
Irrigation- Rs. 4450 (for timber yielding plants) and Rs. 1600 (for fruit yielding plants) (Table 2).

Table 2: Analysis of cost incurred on the JanVan yojana plantation during three years of the plantation 


\begin{tabular}{|c|c|c|}
\hline & 1029.16 & 2830.19 \\
\hline Cost of fertilizer and insecticides etc & 1600 & 700 \\
\hline Sub total expenditure in $1^{\text {st }}$ year & $25,093.66$ & $17,575.99$ \\
\hline \multicolumn{3}{|c|}{ Cost incurred during second year of Plantation (Rs) } \\
\hline labour cost incurred on two weeding & 4 days $X$ Rs. 296/days = & 6 days $X$ Rs. 296/days $=$ \\
\hline $\begin{array}{l}\text { Labour cost@296 per day ( } 15 \% \text { increase in } \\
\text { minimum wages) }\end{array}$ & 1184 & 1776 \\
\hline Cost of fertilizer and insecticides etc & 800 & 350.45 \\
\hline Cost of Irrigation & 1600 & 4450 \\
\hline Sub total expenditure in $2^{\text {nd }}$ year & 3584 & 6576.45 \\
\hline \multicolumn{3}{|c|}{ Cost incurred during third year of Plantation (Rs) } \\
\hline labour cost incurred on two weeding & 4 days $X$ Rs. $340 /$ days $=$ & - \\
\hline $\begin{array}{l}\text { Labour cost@340 per day ( } 15 \% \text { increase in } \\
\text { minimum wages) }\end{array}$ & 1360 & \\
\hline Cost of fertilizer and insecticides etc & 800 & - \\
\hline Cost of Irrigation & 1600 & 4450 \\
\hline Sub total expenditure in $3^{\text {rd }}$ year & 3760 & 4450 \\
\hline Grand total expenditure in three year & 32,438 & 28,602 \\
\hline
\end{tabular}

The present study shows that the income generation from the specified plants of JanVan yojana was high. The income generations of fruit yielding plants start from $3^{\text {rd }}$ year of the plantation in guava to $5^{\text {th }}$ year of the plantation in mango whereas timber yielding plants start after $5^{\text {th }}$ year of the plantation in Eucalyptus and from 78 year of plantation in Teak (Saagwaan). The present study shows that total return from plantation of the mango, guava and Amla on one acre land was Rs. $2,00,000$, Rs. $1,28,000$ and Rs. 3,20,000, respectively (Table 3). The income return in Eucalyptus after $5^{\text {th }}$ year of the plantation was Rs. $8,90,000$ and after 10 years of the plantation was Rs. 1,33,50,000 in one acre of land cultivation. However, income generated from the plantation of teak in one acre land after 7-8 year of the plantation was Rs. 1,25,000 (Tree fell for poles 1000@Rs.125) by thinning of the trees. After 13-14 year of the plantation, thinning was necessary and it gives income of around Rs. 1,37,500 (Tree fell for poles $500 @$ Rs. 275), whereas, after 20 year of the plantation, Rs. 4,87,500 (Tree fell for Heartwood 275 of 65cft@Rs. 7500) has been generated and after 30 year of the plantation income return was Rs. 16,20,000 (Tree fell for Heartwood 275 of 108cft@Rs. 15000) (Table 4).

Table 3: Analysis of income generated from some of the fruit yielding crops of the JanVan yojana plantation

\begin{tabular}{cccc}
\hline \multirow{2}{*}{$\begin{array}{c}\text { From one acre } \\
\text { plantation }\end{array}$} & \multicolumn{2}{c}{ Fruit yielding plants (160 plants per acre) } & Amla \\
\cline { 2 - 3 } & Mango & Guava & (n) \\
\hline Income return from & $5^{\text {th }}$ year of plantation & $3^{\text {rd }}$ year of plantation & \\
Production & 50 quintal & 32 quintal & 40 quintal \\
Total Income & $2,00,000$ & $1,28,000$ & $3,20,000$ \\
& $@ 4000 /$ quintal & $@ 4000 /$ quintal & $@ 8000 /$ quintal \\
\hline
\end{tabular}


Table 4: Analysis of income generated from some of the timber yielding crops of the JanVan yojana plantation

\begin{tabular}{|c|c|c|}
\hline \multirow[b]{2}{*}{ From one acre plantation } & \multicolumn{2}{|c|}{ Timber yielding plants (445 plants per acre) } \\
\hline & Teak (Saagwaan) & Eucalyptus \\
\hline Income return starts from & $7-8$ year of plantation & $5^{\text {th }}$ year of plantation \\
\hline Income after $5^{\text {th }}$ year of plantation & - & $\begin{array}{c}8,90,000 \\
@ 2000 \text { per plant }\end{array}$ \\
\hline Income after 7-8 years of plantation & $\begin{array}{c}1,25,000 \\
\text { (Tree fell for poles } 1000 @ R s .125)\end{array}$ & - \\
\hline Income after $10^{\text {th }}$ year of plantation & - & $\begin{array}{c}1,33,50,000 \\
@ 30,000 \text { per plant }\end{array}$ \\
\hline $\begin{array}{l}\text { Income after } 13-14 \text { years of } \\
\text { plantation }\end{array}$ & $\begin{array}{c}1,37,500 \\
\text { (Tree fell for poles 500@Rs.275) }\end{array}$ & - \\
\hline Income after 20 years of plantation & $\begin{array}{c}4,87,500 \\
\text { (Tree fell for Heartwood } 275 \text { of } \\
\text { 65cft@Rs.7500) }\end{array}$ & - \\
\hline Income after 30 years of plantation & $\begin{array}{c}16,20,000 \\
\text { (Tree fell for Heartwood } 275 \text { of } \\
\text { 108cft@Rs.15000) }\end{array}$ & - \\
\hline
\end{tabular}

\section{DISCUSSION}

We compared JanVan yojana crops with various crops such as Paddy grown in rainy as well as summer season in a year and Wheat, Mustard and gram grown once in a year with a crop span time is around 90-120 days. We found that the net income generated from the various farming systems in a year including Paddy both in the rainy as well as summer season and Mustard together was about Rs. $20,930+10,510+15,425=46,865$, which was still less than projected and estimated income generated from any of the JanVan yojana prescribed crops in one acre of land. The results of current study show that farming of the three different crops in a year could not able to earn as much profit as JanVan yojana plantation. Kumar et al. ${ }^{[16]}$ also observed significantly higher yield and financial yield from the horti-silvicultural system than the sole cropping. Dhillon et al. ${ }^{[17]}$ reported that poplar cultivation results net return annually per acre with intercropping and without intercropping were Rs. 29,332 and Rs. 22,156, respectively. Chauhan et al. ${ }^{[18]}$ reported that the economics of horti-silvicultural system was better than the traditional crops. Getahun ${ }^{[19]}$ also reported twice higher income return from fruit tree based agrofestry cropping system than the monocropping system in Wondo district, Ethiopia. Kurtz ${ }^{[20]}$ also reported that agroforestry systems provide cost- effective alternatives that can increase profits and meets environmental goals. Horticultural cropping systems can able to provide higher income sustainability than existing traditional agricultural cropping system on the same area of land ${ }^{[21]}$. Sharma et al. ${ }^{[22]}$ carried out different farming system experiments in various villages of Bhilwara district of Rajasthan and found that net return was increased by 2 to 5 times as compared to conventional cropping systems.

\section{CONCLUSIONS}

This comparative study on income generation through agriculture crop and JanVan yojana crops including both fruit and timber yielding crops at farmer's level suggests that horticultural fruit crops and silviculture are capable of more income generation than other traditional crops. It is therefore suggested to the farmers to adopt and incorporate fruit crops in their barren private land as well as timber crops on the ridge of the field with the traditional crops. Finally, Jan Van Yojana must be proved a boon to the farmers in making their income double and also as a stepping stone for the self-sustaining Jharkhand.

\section{ACKNOWLEDGMENTS}

The authors are thankful to the Professor \& Head, Department of Botany, Ranchi University for providing all 
the necessary facilities and also gratefully acknowledge the Reviewers for their valuable comments and suggestion on the earlier version of this paper.

\section{CONTRIBUTION OF AUTHORS}

Research concept- Md. Shahzad Ahmad, Dr. Jyoti Kumar Research design- Md. Shahzad Ahmad, Dr. Jyoti Kumar

Supervision- Dr. Jyoti Kumar

Materials- Md. Shahzad Ahmad

Data collection- Md. Shahzad Ahmad

Data analysis and Interpretation- Md. Shahzad Ahmad, Dr. Naheed Irfan

Literature search- Md. Shahzad Ahmad, Dr. Naheed Irfan Writing article- Md. Shahzad Ahmad, Dr. Naheed Irfan Critical review- Dr. Jyoti Kumar, Md. Shahzad Ahmad

Article editing- Md. Shahzad Ahmad, Dr. Naheed Irfan, Dr. Jyoti Kumar

Final approval- Dr. Jyoti Kumar

\section{REFERENCES}

[1] Jharkhand Economic Survey. Tribal Welfare and Interventions for the Underprivileged. 2016-17; pp. 31.

[2] Saha M, Sengupta S. Symbiotic relationship between forest and tribe: a case study of santal tribe of Jaypur forest Bankura District, West Bengal, India. Trans. Inst. Indian Geog., 2014; 36: 2.

[3] Tscharntke T, Klein AM, Kruess A, Steffan-Dewenter I, Thies C. Landscape perspectives on agricultural intensification and biodiversity-ecosystem service management. Ecol Lett., 2005; 8: 857-74.

[4] Priess JA, Mimler $M$, Klein AM, Schwarze $S$, Tscharntke $T$, et al. Linking deforestation scenarios to pollination services and economic returns in coffee agroforestry systems. Ecol Appl., 2007; 17: 407-17.

[5] Flynn DF, Gogol-Prokurat M, Nogeire T, Molinari N, Richers BT, et al. Loss of functional diversity under land use intensification across multiple taxa. Ecol Lett., 2009; 12: 22-33.

[6] Senior MJ, Hamer KC, Bottrell S, Edwards DP, Fayle TM, et al. Trait dependent declines of species following conversion of rain forest to oil palm plantations. Bio Divers Conserv., 2013; 22: 253-68.

[7] Deguines N, Jono C, Baude M, Julliard R, Fontaine C. Largescale trade-off between agricultural intensification and pollination. Front Ecol Environ., 2014; 12 : 212-17.
[8] Kumar V. Multifunctional agroforestry systems in tropics region. Nat Environ Poll Tech., 2016; 15(2): 365-76.

[9] Kumar V. Importance of Home-gardens Agroforestry System in Tropics Region. In: Prithwraj Jha (eds), Biodiversity, Conservation and Sustainable Development. New Academic Publishers, New Delhi. Issues and Approaches, 2017; 2: 1-27.

[10]Kumar V. Estimation of carbon sequestration of agroforestry systems. Van Sangyan., 2015; 2(5): 1723.

[11]Nissen TM, Midmore DJ, Keeler AG. Biophysical and economic tradeoffs of intercropping timber with food crops in the Philippine uplands. Agricul Syst., 2001; 67(1): 49-69.

[12]Government of Jharkhand, Department of Forest, Environment and Climate change, 2015-16; Resolution No. 5965 date-27.11.2015, pp. 3.

[13]CM JanVan Yojana Booklet, Department of Forest, Environment and Climate change Government of Jharkhand, 2016.

[14]Government of Jharkhand, Department of Forest, Environment and Climate change, 2018-19; Resolution No. 2005 date-14.05.2018, pp. 6.

[15]Dillon TL, John I, Hardakar JB. Farm Management research for small farmer development. FAO Bull., 1989; 41: 21-49.

[16]Kumar S, Malik MS, Kumar V. Economics and Yield Performance of Gamhar (Gmelina arborea roxb.) Under Agri-silvicultural System in East Singhbhum District in Jharkhand, India. In Climate Change and Agroforestry (Pandey CB, Gaur MK, Goyal RK: Eds) New India Publishing Agency, New Delhi, India, 2017; pp. 579-91.

[17]Dhillon A, Sangwan V, Malik DP, Lubach MS. An economic analysis of poplar cultivation. Indian For., 2001; 127: 86-90.

[18]Chauhan SK, Sharma R, Dhillon WS. Status of intercropping in poplar based agroforestry in India. For Bull., 2012; 12: 49-67.

[19]Getahun KM. Economic analysis and determinants of fruit tree based agroforestry system in Wondo district, Ethiopia: comparative analysis with monocropping systems. MSc Thesis, Wondo Genet College of Forestry and Natural Resources, Hawassa University, Ethiopia, 2012. 
[20]Kurtz WB. Economics and policy of agroforestry. In: Garrett HE, Rietveld WJ, Fisher RF. (eds), North American Agroforestry: An Integrated Science and Practice. American Society of Agronomy, Madison, WI, USA: 2000; pp. 321-60.

[21]Gill MS, Singh JP, Gangwar KS. Integrated farming System and agriculture sustainability. Indian J Agron., 2009; 54(2): 128-39.
[22]Sharma SK, Sharma RK, Jajoria D, Kumar A. Enhancing income and resource conservation through micro farming systems. (In) Proceedings of National Symposium on Agricultural Diversification for Sustainable Livelihood and Environmental Security, held during 18-20 November 2014 at Ludhiana, Punjab, 2014; pp. 561-62. 